Volume 6 Nomor 1 Agustus 2020 - Januari 2021

Jurnal
Belo

DOI: https://doi.org/10.30598/belovol6issue1page73-88 p-ISSN : 2460-6820 | e-ISSN : 2686-5920

Penerbit : Fakultas Hukum Universitas Pattimura

\title{
Eksistensi Ancaman Pidana Mati Dalam Tindak Pidana Korupsi Pada Masa Pandemik Covid-19
}

\author{
Elias Zadrack Leasa ${ }^{1, *}$ \\ ${ }^{1}$ Fakultas Hukum Universitas Pattimura \\ eliaszleasa72@gmail.com ${ }^{1}$ \\ *Corespondence Author
}

\begin{abstract}
Abstrak
Pembentukan Undang-undang Tindak Pidana Korupsi merupakan upaya penanggulangan atau pemberantasan tindak pidana korupsi. Pidana Mati merupakan salah satu alat untuk menjerat dan mendatangkan efek jera kepada pelaku. Namun kebijakan perumusan ancaman pidana mati sebagai pemberatan pidana apabila dilakukan dalam keadaan tertentu misalnya bencana alam. Corona Virus Disease 2019 (COVID-19) merupakan bencana non-alam yang ditetapkan sebagai Bencana Nasional sangatlah tidak mungkin untuk menjatuhkan pidana mati dikarenakan Covid-19 bukan termasuk bencana alam nasional, juga penentuan besaran nilai kerugian dalam tindak pidana korupsi yang masih kabur penganturannya.
\end{abstract}

Kata Kunci: Korupsi, Pidana Mati, Covid-19

Naskah dikirim: 17 Juli 2020|Direvisi : 10 Agustus 2020|Diterbitkan: 28 Agustus 2020 


\begin{abstract}
The formation of the Corruption Crime Law is an effort to overcome or eradicate corruption crimes. Death Penalty is one of the tools to ensnare and have a deterrent effect on the perpetrator. However, the policy on the formulation of the death penalty is a criminal burden if it is carried out in certain circumstances, such as a natural disaster. Corona Virus Disease 2019 (COVID-19) is a non-natural disaster designated as a National Disaster, it is impossible to impose a death penalty because Covid-19 is not a national natural disaster, as well as determining the amount of loss in criminal acts of corruption which is still obscure.
\end{abstract}

\title{
Keywords: Corruption, Death Penalty, Covid-19
}

\section{Pendahuluan}

Korupsi merupakan kejahatan yang luar biasa (extra ordinary crime). Hal ini beralasan karena perbuatan korupsi menimbulkan dampak yang sangat luar biasa bukan saja dapat merugikan keuangan negara tetapi juga dapat menimbulkan kerugian-kerugian pada perekonomian rakyat. Sebagai kejahatan yang luar biasa tersebut maka perbuatan korupsi penanganannya harus luar biasa pula.

Korupsi diartikan sebagai perbuatan jahat (kejahatan), yakni suatu perbuatan kebusukan, dapat disuap, tidak bermoral, kebejatan dan ketidakjujuran, sudah tentu yang dimaksudkan di sini ialah moral atau akhlak oknum yang melakukan perbuatan korupsi sebab orang yang bermoral baik tentu tidak akanmelakukan korupsi““. ${ }^{1}$ Andi Hamzah, dalam kamus hukumnya mengartikan korupsi sebagai suatu perbuatan buruk, busuk, bejat, suka disuap, perbuatan yang menghina atau mefitnah, menyimpang dari kesucian, tidak bermoral. $^{2}$

${ }^{1}$ S, Mailoa, (2006) Perilaku dan Budaya Korupsi Dalam Konteks Penegakan Hukum di Indonesia, Pidato Pengukuhan Guru Besar Dalam Bidang Ilmu Hukum Pidana pada Fakultas Hukum Universitas Pattimura.

${ }^{2}$ Andi Hamzah, (2015) Pemberantasan Korupsi Melalui Hukum Nasional dan Internasional, Raja Grafindo Persada, Jakarta, , hal. 4

DOI: https://doi.org/10.30598/belovol6issue1page73-88 
Upaya untuk menanggulangi perbuatan korupsi yang terjadi di mana-mana memang telah banyak dilakukan, baik dengan menggunakan pendekatan penegakan hukum pidana, yakni dengan mengutamakan pengenaan sanksi pidana yang berat, demikian juga dengan mengutamakan pendekatan penanggulangan secara administratif, ${ }^{3}$ yakni berbagai pengawasan dimasing-masing lingkup instansi. Namun, tidak dapat disangkal bahwa ternyata pendekatan tersebut belum dapat menyelesaikan dan atau mentuntaskan perbuatan korupsi.

Hal ini menjadi penting mengingat dampak dari tindak pidana korupsi yang merusak sendi-sendi kehidupan bangsa dalam berbagai aspek, dan proses penanggulangannya telah dilakukan berdasarkan beberapa peraturan perundangundangan tentang Tindak Pidana Korupsi, antara lain Undang-undang 31 Tahun 1999 Tentang Pemberantasan Tindak Pidana Korupsi sebagaimana dirubah dengan Nomor 20 Tahun 2001. Dalam rangka mencapai tujuan yang lebih efektif untuk mencegah dan memberantas tindak pidana korupsi, Undang-undang ini memuat ketentuan pidana yang berbeda dengan Undang-undang sebelumnya, yaitu menentukan ancaman pidana minimum khusus, pidana denda yang lebih tinggi, dan ancaman pidana mati yang merupakan pemberatan pidana. Selain itu, Undang-undang ini memuat juga pidana penjara bagi pelaku tindak pidana korupsi yang tidak dapat membayar pidana tambahan berupa uang pengganti kerugian negara.

Pidana mati terhadap pelaku tindak pidana korupsi diatur dalam Pasal 2 Undangundang Pemberantasan Tindak Pidana Korupsi disebutkan :

(1) Setiap orang yang secara melawan hukum melakukan perbuatan memperkaya diri sendiri atau orang lain atau suatu korporasi yang dapat merugikan keuangan negara atau perekonornian negara, dipidana dengan pidana penjara seumur hidup atau pidana penjara paling singkat 4 (empat) tahun dan paling

\footnotetext{
${ }^{3}$ Romli Atmasasmita, (2016) Sistem Peradilan Pidana (Criminal Justice System), Perspektif Eksistensialisme dan Abolisionisme, Binacipta, Bandung, hal. 17

DOI: https://doi.org/10.30598/belovol6issue1page73-88 
lama 20 (dua puluh) tahun dan denda paling sedikit Rp 200.000.000,00 (dua ratus juta rupiah) dan paling banyak Rp 1.000.000.000,00 (satu miliar rupiah).

(2) Dalam hal tindak pidana korupsi sebagaimana dimaksud dalam ayat (1) dilakukan dalam keadaan tertentu, pidana mati dapat dijatuhkan.

Pasal 2 ayat (2) menyebutkan bahwa pidana mati dapat dikenakan kepada pelaku tindak pidana korupsi jika dilakukan dalam keadaan tertentu, jadi pidana mati merupakan pemberatan pidana bila memenuhi syarat pemberatan yakni keadaan tertentu tersebut. Dalam penjelasan pasal 2 ayat (2) yakni yang dimaksud dengan "keadaan tertentu" dalam ketentuan ini dimaksudkan sebagai pemberatan bagi pelaku tindak pidana korupsi apabila tindak pidana tersebut dilakukan pada waktu negara dalam keadaan bahaya sesuai dengan undang-undang yang berlaku, pada waktu terjadi bencana alam nasional, sebagai pengulangan tindak pidana korupsi, atau pada waktu negara dalam keadaan krisis ekonomi dan moneter.

Saat ini Indonesia bahkan bangsa-bangsa di dunia sedang berada pada situasi pandemi Covid-19. Di Indonesia status keadaan darurat wabah Covid-19 di Indonesia terhitung 91 hari sejak tanggal 29 Februari 2020 hingga 29 Mei 2020 yang ditetapkan melalui Keputusan Kepala BNPB No. 13.A Tahun 2020 tentang Perpanjangan Status Keadaan Tertentu Darurat Bencana Wabah Penyakit AKIBAT Virus Corona di Indonesia. Dampak dari wabah virus corona ini tentu saja sangat dirasakan karena dampaknya terhadap krisis ekonomi dan moneter.

Virus corona merupakan bencana non-alam yang termaktub dalam Undang-undang Nomor 24 Tahun 2007 tentang Penanggulangan Bencana, pada pasal 1 angka 3 menyebutkan bahwa bencana non-alam adalah bencana yang diakibatkan oleh peristiwa atau rangkaian peristiwa non-alam yang antara lain berupa gagal teknologi, gagal 
modernisasi, epidemi, dan wabah penyakit. Virus Covid-194 merupakan suatu penyakit yang dikatakan sebagai epidemik apabila sudah mewabah ke lebih dari satu area, dengan tingkat penyebaran yang cepat dan sulit diprediksi bahkan dikatakan sebagai pandemik karena tingkat penyebarannya yang cepat secara global di seluruh dunia.

Pidana berasal dari kata straf (Belanda), yang pada dasarnya dapat dikatakan sebagai suatu penderitaan (nestapa) yang sengaja dikenakan/dijatuhkan kepada seseorang yang telah terbukti bersalah melakukan suatu tindak pidana. ${ }^{5}$ Istilah pidana diartikan sebagai sanksi pidana, selain itu juga diartikan dengan istilah-istilah lain yaitu hukuman, penghukuman, pemidanaan, penjatuhan hukuman, pemberian pidana dan hukuman pidana. ${ }^{6}$ Sudarto memberikan pengertian pidana sebagai penderitaan yang sengaja dibebankan kepada orang yang melakukan perbuatan yang memenuhi syarat-syarat tertentu. Sedangkan Roeslan mengartikan pidana sebagai reaksi atas delik, dan itu berujud suatu nestapa yang dengan sengaja ditimpakan negara kepada pelaku delik itu. ${ }^{7}$

Pada dasarnya kepada seseorang pelaku suatu tindak pidana harus dikenakan suatu akibat hukum. Akibat hukum itu pada umumnya berupa pidana. Ditinjau dari sudut kerugian terpidana, pidana dapat mengenai, beberapa hal sebagai berikut :

a. Jiwa pelaku: pidana mati;

b. Badan pelaku: pencambukan dengan rotan sekian kali, pemotongan bagian badan (misalnya jati tangan), "dicap bara" (brandmerk) dan lain sebagaimnya;

c. Kemerdekaan pelaku: pidana penjara, pidana tutupan, pidana kurungan, pembuangan (vernbannig), pengasingan (deportatie), pengusiran, pengintemiran, penawanan dan sebagainya;

\footnotetext{
${ }^{4}$ Pengertian Penyakit Endemik dan Jenis yang Masih Ada di Indonesia, Dalam:https://www.sehatq.com/ diakases 19 Juli 2020

${ }^{5}$ Muladi dan Barda Nawawi Arief, (2015) Teori-Teori dan Kebijakan Pidana, Alumni, Bandung, hal. 1.

${ }^{6}$ Mahrus Ali, (2017), Dasar-dasar Hukum Pidana, Sinar Grafika, Jakarta, , hal. 185

${ }^{7}$ Ibid, hal. 186.
}

DOI: https://doi.org/10.30598/belovol6issuelpage73-88 
d. Kehormatan pelaku: pencabutan hak-hak tertentu, pencabutan suat izin mengemudi, pengumuman putusan hakim, tegoran dan lain sebagainya;

e. Harta benda/kekayaan: pidana denda, perampasan barang (tertentu), membayar suatu barang yang tidak/belum dirampas sesuai tafsiran dan lain sebagainya. ${ }^{8}$

Jenis pidana tercantum dalam Pasal 10 KUHP.Jenis pidana tersebut dibedakan antara pidana pokok dan pidana tambahan.Pidana tambahan hanya dijatuhkan jika pidana pokok dijatuhkan, kecuali dalam hal tertentu. ${ }^{9}$ Pidana tersebut adalah:

a. Pidana Pokok terdiri dari :

1. Pidana mati

2. Pidana penjara

3. Pidana kurungan

4. Pidana denda

5. Pidana tutupan

b. Pidana Tambahan terdiri dari :

1. Pencabutan hak-hak tertentu

2. perampasan barang-barang tertentu

3. pengumuman putusan hakim

Berdasarkan ketentuan Undang-Undang Nomor 31 Tahun 1999 jo Undang-Undang Nomor 20 Tahun 2001, jenis sanksi yang dapat dijatuhkan oleh hakim terhadap terdakwa tindak pidana korupsi adalah:

1. Pidana Mati

Dapat dipidana mati karena kepada setiap orang yang secara melawan hukum melakukan perbuatan memperkaya diri sendiri atau orang lain atau suatu korporasi yang dapat merugikan Keuangan Negaraatau perekonomian Negara

${ }^{8}$ Kanter E. Y. dan Sianturi S. R, (2017) Asas-Asas Hukum Pidana Di Indonesia Dan Penerapannya, Storia Grafika, Jakarta, hal. 452

${ }^{9}$ Andi Hamzah, (2016) Asas-asas Hukum Pidana, Rineka Cipta, Jakarta, hal. 183

DOI: https://doi.org/10.30598/belovol6issuelpage73-88 
sebagaimana ditentukan dalam Pasal 2 ayat 1 Undang-UndangNomor 20 Tahun 2001 tentang Pemberantasan Tindak Pidana Korupsi yang dilakukan dalam keadaan tertentu.

2. Pidana Penjara terdiri dari :

a. Pidana penjara seumur hidup atau pidana penjara paling singkat 4 tahun dan paling lama 20 tahun dan denda paling sedikit Rp. 200.000.000,00 dan paling banyak Rp. 1.000.000.000,00 bagi setiap orang yang secara melawan hukum melakukan perbuatan memperkaya diri sendiri atau orang lain atau suatu korporasi yang dapat merugikan Keuangan Negara atau perekonomian Negara (Pasal 2 ayat 1).

b. Pidana penjara seumur hidup atau pidana penjara paling singkat 1 tahun dan atau denda paling sedikit Rp. 50.000.000,00 dan paling banyak Rp. 1.000.000.000,00 bagi setiap orang yang dengan tujuan menguntungkan diri sendiri atau orang lain atau suatu korporasi, menyalahgunakan kewenangan, kesempatan atau sarana yang ada padanya karena jabatan atau kedudukan yang dapat merugikan Keuangan Negara atau perekonomian Negara (Pasal $3)$.

c. Pidana penjara paling singkat 3 tahun dan paling lama 12 tahun dan atau denda paling sedikit Rp. 150.000.000,00 dan paling banyak Rp. 600.000.000,00 bagi setiap orang yang dengan sengaja mencegah, merintangi atau menggagalkan secara langsung atau tidak langsung penyidikan, penuntutan dan pemeriksaan di sidang pengadilanterhadap tersangka atau terdakwa ataupun para saksi dalam perkara korupsi (Pasal 21).

d. Pidana penjara paling singkat 3 tahun dan paling lama 12 tahun dan atau denda paling sedikit Rp. 150.000.000,00 dan paling banyak Rp. $600.000 .000,00$ bagi setiap orang sebagaimana dimaksuddalam pasal 28 , pasal 29, pasal 35 dan pasal 36.

DOI: https://doi.org/10.30598/belovol6issue1page73-88 
3. Pidana Tambahan terdiri dari :

a. Perampasan barang bergerak yang berwujud atau yang tidak berwujud atau barang yang tidak bergerak yang digunakan untuk atau yang diperoleh dari tindak pidana korupsi, termasuk perusahaan milik terpidana dimana tindak pidana korupsi dilakukan, begitu pula dari barang-barang yang menggantikan barang-barang tersebut.

b. Pembayaran uang pengganti yang jumlahnya sebanyak-banyaknya sama dengan harta yang diperoleh dari tindak pidana korupsi.

c. Penutupan seluruh atau sebagian perusahaan untuk waktu paling lama 1 tahun.

d. Pencabutan seluruh atau sebagian hak-hak tertentu atau penghapusan seluruh atau sebagian keuntungan tertentu yang telah atau dapat diberikan oleh pemerintah kepada terpidana. e. jika terpidana tidak membayar uang pengganti paling lama dalam waktu 1 bulan sesudah putusan pengadilan yang telah memperoleh kekuatan hukum tetap maka harta bendanya dapat disita oleh Jaksa dan dilelang untuk menutupi uang pengganti tersebut.

e. jika terpidana tidak mempunyai harta benda yang mencukupi untuk membayar uang pengganti maka terpidana dengan pidana penjara yang lamanya tidak memenuhi ancaman maksimum dari pidana pokoknya, dan lamanya pidana tersebut sudah ditentukan dalam putusan pengadilan.

4. Terhadap tindak pidana yang dilakukan oleh atau atas nama korporasi maka pidana pokok yang dapat dijatuhkan adalah pidana denda dengan ketentuan maksimal ditambah $1 / 3$.

Ancaman Pidana Mati Dalam Tidak Pidana Korupsi Pada Masa Pandemik Covid19

Negara Indonesia dalam mencapai cita hukumnya, sesuai pada Pasal 27 ayat (1) Undang-Undang Dasar Negara Republik Indonesia Tahun 1945 yang berbunyi : "segala warga negara bersamaan kedudukannya di dalam hukum dan pemerintahan DOI: https://doi.org/10.30598/belovol6issuelpage73-88 
dan wajib menjunjung hukum dan pemerintahan itu dengan tidak ada kecualinya." Berdasarkan hal tersebut maka setiap sikap, kebijakan dan perilaku alat negara dan penduduk (warga negara dan orang asing) harus berdasarkan dan sesuai dengan hukum.

Dalam upaya mewujudkan kehidupan yang damai, aman dan tentram, diperlukan adanya aturan untuk mengatur kehidupan sosial masyarakat agar sesama manusia dapat berperilaku dengan baik dan rukun. Namun, gesekan dan perselisihan antar sesama manusia tidaklah dapat dihilangkan. Oleh karena itu, hukum diberlakukan terhadap siapapun yang melakukan perbuatan melanggar hukum.

Sistem Peradilan Pidana harus menjamin supaya semua pelaku yang menjalaninya harus dijamin hak-haknya. ${ }^{10}$ Siapapun sebagai pelaku tindak pidana korupsi harus diperlakukan secara adil dan persoalan penyelesaian kasus korupsi harus benar-benar menjadi prioritas pemerintah, sebab kasus korupsi selalu berhubungan dengan basic economic and economic life of the nation. Selain itu penyelesaian kasus korupsi juga untuk menumbuhkan kepercayaan investor asing dalam menanamkan modalnya di Indonesia. Banyak keluhan dari investor asing di Indonesia bahwa kendala investasi yang paling berat adalah selain langkanya tenaga profesional, birokrasi yang bertele-tele juga issue yang sangat peka yaitu korupsi. ${ }^{11}$

Korupsi merupakan kejahatan yang luar biasa, maka dalam penanganannya harus dilakukan dengan luar biasa. Pembuat undang-undang korupsi memformulasikan beberapa hal penting, yang dianggap dapat dipakai sebagai alat untuk menjerat dan mendatangkan efek jera kepada pelaku, yakni asas pembuktianterbalik dan sanksi yang berat, termasuk pidana mati.

Di Belanda pidana mati yang dahulu kala bersama-sama dengan sejumlah pidana badan lainnya merupakan pidana paling utama dan kadangkala eksekusinya dilakukan

\footnotetext{
${ }^{10}$ Anakotta, M. (2019). Kebijakan Sistem Penegakan Hukum Terhadap Penanggulangan Tindak Pidana Terorisme Melalui Pendekatan Integral. Jurnal Belo, 5(1), 46-66. DOI : https://doi.org/10.30598/belovol5issue1page46-66

11 Edi Setiadi, Penegakan Hukum Pidana Terhadap Kasus-Kasus Korupsi Dalam Menciptakan Clean Government, Mimbar No. 4 Th.XVI Okt. - Des. 2000 - 305

DOI: https://doi.org/10.30598/belovol6issue1page73-88 
dalam bentu-bentuk khusus, telah dihapus berdasarkan undang-undang tertanggal 17 September 1870 , Staatblad $162 .{ }^{12}$ Pidana mati adalah salah satu jenis pidana yang paling tua, setua umat manusia.Pidana mati juga merupakan bentuk pidana yang paling menarik dikaji oleh para ahli karena memiliki nilai kontradiksi atau pertentangan yang tinggi antara yang setuju dengan yang tidak setuju. ${ }^{13}$

Pidana mati dikenakan dalam upaya penanggulangan tindak pidana korupsi sebagai kejahatan yang luar biasa, pembuat undang-undang memformulasikan pidana mati dalam tindak pidana korupsi sebagai alat untuk menjerat dan mendatangkan efek jera kepada pelaku, yakni asas pembuktian terbalik dan sanksi yang berat, termasuk pidana mati. ${ }^{14}$

Kebijakan formulasi pasal-pasal yang berkaitan dengan pidana mati tentu didasarkan pada pemikiran dan dilatarbelakangi oleh keinginan untuk memberantas tindak pidana korupsi.Namun, kebijakan formulasi ini tidak diikuti oleh kebijakan aplikasi. Sebagaimana keseriusan pemerintah (pembuat undang-undang) yang mencantumkan pidana mati pada Pasal 2 ayat (2) Undang-undang Korupsi karena enggan untuk menerapkan ancaman pidana mati terhadap pelaku tindak pidana, meskipun nyatanyata negara telah dirugikan milyaran, bahkan trilyunan rupiah, dan banyak anggota masyarakat kehilangan kesempatan untuk menikmati kesejahteraan akibat dari tindak pidana tersebut.

Menurut Ketua Komisi Yudisial Busyro Muqodas, ada 3 kriteria utama yang membuat seorang pelaku tindak pidana korupsi layak dijatuhi hukuman mati yakni :

1. Nilai uang negara yang dikorupsi lebih dari Rp 100 miliar dan secara massif telah merugikan rakyat;

2. Pelaku tindak pidana korupsi tersebut adalah pejabat negara;

12 Jan Remmelink, (2013) Hukum Pidana Komentar atas Pasal-Pasal Terpenting dari Kitab Undang Undang Hukum Pidana Belanda dan Padanannya Ddalam Kitab undang Undang Hukum Pidana Indonesia, Gramedia Pusaka Utama, Jakarta, hal. 459

${ }^{13}$ Mahrus Ali, Op Cit, hal. 195.

${ }^{14}$ Elsa R. M. Toule, Eksistensi Ancaman Pidana Mati Dalam Undang-Undang Tindak Pidana Korupsi, Jurnal Hukum Prioris, Vol. 3 No. 3, Tahun 2013, hal. 104

DOI: https://doi.org/10.30598/belovol6issuelpage73-88 
3. Pelaku korupsi sudah berulang-ulang kali melakukan korupsi. ${ }^{15}$

Sifat korup penguasa suatu daerah mengakibatkan daerahbya tidak berkembang dengan baik, untuk itu perilaku korup harus dilawan. ${ }^{16}$ Salah satu penyebab tidak diterapkannya ancaman pidana mati kepada koruptor karena perumusan ancaman pidana mati diikuti dengan syarat dalam "keadaan tertentu" (Pasal 2 ayat (2) Undang-undang No. 31 Tahun 1999). ${ }^{17}$ Dalam penjelasan Pasal ini dirumuskan bahwa, yang dimaksud dengan keadaan dengan "keadaan tertentu" dalam ketentuan ini dimaksudkan sebagai pemberatan bagi pelaku tindak pidana korupsi apabila tindak pidana tersebut dilakukan pada waktu negara dalam keadaan bahaya sesuai dengan undang-undang yang berlaku, pada waktu terjadi bencana alam nasional, sebagai pengulangan tindak pidana korupsi, atau pada waktu negara dalam keadaan krisis ekonomi dan moneter. Jadi syarat "keadaan tertentu" sebagai pemberatan dalam penjatuhan pidana mati menjadi satu kesatuan hanya untuk poin 4 karena ada kata "atau" yakni sebagai berikut :

1. dilakukan pada waktu negara dalam keadaan bahaya sesuai dengan undangundang yang berlaku;

2. pada waktu terjadi bencana alam nasional ;

3. sebagai pengulangan tindak pidana korupsi, atau

4. pada waktu negara dalam keadaan krisis ekonomi dan moneter.

Sedangkan dalam penjelasan Pasal 2 ayat (2) Undang-undang Nomor 21 Tahun 2002, yang dimaksud dengan "keadaan tertentu" dalam ketentuan ini adalah keadaan yang dapat dijadikan alasan pemberatan pidana bagi pelaku tindak pidana korupsi yaitu apabila tindak pidana tersebut dilakukan terhadap dana-dana yang diperuntukkan bagi penanggulangan keadaan bahaya, bencana alam nasional, penanggulangan akibat kerusuhan sosial yang meluas, penanggulangan krisis ekonomi dan moneter,

\footnotetext{
${ }^{15}$ Ibid, hal. 106

${ }^{16}$ Corputty, P. (2019). Masa Tenang Kampanye Politik Pada Media Sosial Dan Ketentuan Pemidanaanya. Jurnal Belo, 5(1), 110-122. DOI : https://doi.org/10.30598/belovol5issue1page110-122

${ }^{17}$ Patty, J. (2019). jmp Pelarangan Mantan Terpidana Korupsi Menjadi Calon Kepala Daerah Agar Menimbulkan Efek Jera. JURNAL BELO, 5(1), 1-9. https://doi.org/10.30598/belovol5issue1page1-9

DOI: https://doi.org/10.30598/belovol6issue1page73-88 
danpengulangan tindak pidana korupsi. Jadi syarat "keadaan tertentu" sebagai pemberatan dalam penjatuhan pidana mati mengalami perubahan namun tetap menjadi satu kesatuan sebagai berikut $:^{18}$

1. dilakukan terhadap dana-dana yang diperuntukkan bagi penanggulangan keadaan bahaya;

2. bencana alam nasional;

3. penanggulangan akibat kerusuhan sosial yang meluas;

4. penanggulangan krisis ekonomi dan moneter, dan

5. pengulangan tindak pidana korupsi.

Ketentuan tersebut di atas mendapat tanggapan dari Artidjo Alkostar, yang menyatakan ketentuan korupsi yang dilakukan pada waktu negara dalam keadaan bahaya, terjadi bencana alam nasional, pengulangan tindak pidana korupsi, atau negara dalam keadaan krisis ekonomi dan moneter, malah kontradiksi dengan pemberantasan korupsi sebab tidak jelas parameternya. ${ }^{19}$

Ketidakjelasan parameter seperti dikemukakan di atas bukanlah merupakan alasan yang menyebabkan hingga kini belum ada hukuman mati bagi koruptor di Indonesia. Hukuman terberat yang pernah dikenakanterhadap koruptor di Indonesia adalah hukuman seumur hidup yang pernah dikenai terhadap Dicky Iskandar Dinata yang waktu terbukti melakukan tindak pidana korupsi secara berulang, terhadap Bank Duta dan Bank BNI.

Pasal 2 ayat (2) Undang-undang Pemberantasan Tindak Pidana Korupsi yang mengatur tentang dapat dipidanamatinya seorang koruptor, secara faktual tidak pernah diterapkan karena syarat keadaan tertentu tidak terpenuhi olehkoruptor, untuk paramenter "keadaan tertentu" apabila tindak pidana tersebut dilakukan terhadap dana-dana yang diperuntukkan bagi penanggulangan bencana alam nasional.

${ }^{18}$ Latukau, F. (2020). Pengadopsian UNCAC Mengenai Pengembalian Aset Hasil Korupsi Yang Dibawa Atau Disimpan Ke Luar Negeri Dalam Penegakan Hukum Indonesia. Jurnal Belo, Volume 5 Nomor 1. DOI: https://doi.org/10.30598/belovol5issue1page10-31

${ }^{19} \mathrm{Ibid}$, hal. 106

DOI: https://doi.org/10.30598/belovol6issue1page73-88 Copyright (c) 2020 Author 
Dalam Undang-undang Nomor 24 Tahun 2007 tentang Penanggulangan Bencana, pada Pasal 1 angka 1 menyebutkan Bencana adalah peristiwa atau rangkaian peristiwa yangmengancam dan mengganggu kehidupan dan penghidupanmasyarakat yang disebabkan, baik oleh faktor alamdan/atau faktor non-alam maupun faktor manusia sehinggamengakibatkan timbulnya korban jiwa manusia, kerusakanlingkungan, kerugian harta benda, dan dampak psikologis. Jadi berdasarkan Pasal 1 angka 1 tersebut diatas maka bencana terbagi atas 2 (dua) yakni : 1). bencana alam, dan 2). bencana non-alam.

Pada pasal 1 angka 2 undang-undang penanggulangan bencana menyebutkan Bencana alam adalah bencana yang diakibatkan olehperistiwa atau serangkaian peristiwa yang disebabkan olehalam antara lain berupa gempa bumi, tsunami, gunungmeletus, banjir, kekeringan, angin topan, dan tanahlongsor. Sedangkan Pasal 1 angka 3 menyebutkan Bencana non-alam adalah bencana yang diakibatkan olehperistiwa atau rangkaian peristiwa non-alam yang antaralain berupa gagal teknologi, gagal modernisasi, epidemi, danwabah penyakit.

Covid-19 merupakan bencana non-alam, Covid-19 ini penyebarannya sangat cepat dan meluas secara global diseluruh dunia sehingga dikenal dengan istilah Pandemik Covid-19. Di Indonesia status keadaan darurat wabah Covid-19 terhitung 91 hari sejak tanggal 29 Februari 2020 hingga 29 Mei 2020 yang ditetapkan melalui Keputusan Kepala BNPB No. 13.A Tahun 2020 tentang Perpanjangan Status Keadaan Tertentu Darurat Bencana Wabah Penyakit Akibat Virus Corona di Indonesia. Kemudian Presiden mengeluarkan Keputusan Presiden (Keppres) Republik Indonesia Nomor 12 Tahun 2020 tentang Penetapan Bencana Non-Alam Penyebaran Corona Virus Disease 2019 (COVID19) sebagai Bencana Nasional.

Pemerintah telah menetapkan Covid-19 merupakan bencana non-alam dan sesuai dengan Keppres No. Nomor 12 Tahun 2020 bahwa Covid-19 merupakan bencana nasional, namun dalam penjelasan Pasal 2 ayat (2) mengenai parameter keadaan tertentu yakni bencana alam nasional maka sangatlah mustahil pidana mati itu dapat dijatuhkan kepada pelaku mengingat bahwa dalam penjelasan tersebut menentukan bencana alam DOI: https://doi.org/10.30598/belovol6issuelpage73-88 
nasional. Hal lain juga yang sangat mustahil pidana mati dijatuhkan karena tidak adanya batas nilai kerugian keuangan negara atau perekonomian negara.

\section{Penutup}

Rumusan ancaman pidana mati dalam tindak pidana korupsi mengindikasi kekurang seriusan dan kemauan semua pihak terutama lembaga legislatifdalam uapaya penanggulangan atau pemberantasan tindak pidana korupsi. Pada Masa Pandemik Covid19 yang merupakan bencana non-alam bukan merupakan parameter dalam penjatuhan pidana mati karena dalam undang-undang tindak pidana korupsi menyatakan dalam penjelasannya bahwa harus dalam keadaan bencana alam nasional, sedangkan covid merupakan bencana non-alam, juga mengenai besaran nilai kerugian negara dan perekonomian negara yang masih kabur. Jadi eksistensi ancaman pidana mati sangatlah sulit untuk dijatuhkan kepada pelaku karena parameter yang tidak jelas dari keadaan tertentu tersebut.

\section{Daftar Pustaka}

\section{Jurnal}

[1] Anakotta, M. (2019). Kebijakan Sistem Penegakan Hukum Terhadap Penanggulangan Tindak Pidana Terorisme Melalui Pendekatan Integral. Jurnal Belo, 5(1), 46-66. DOI : https://doi.org/10.30598/belovol5issue1page46-66

[2] Corputty, P. (2019). Masa Tenang Kampanye Politik Pada Media Sosial Dan Ketentuan Pemidanaanya. Jurnal Belo, 5(1), 110-122. DOI : https://doi.org/10.30598/belovol5issue1page110-122

[3] Latukau, F. (2020). Pengadopsian UNCAC Mengenai Pengembalian Aset Hasil Korupsi Yang Dibawa Atau Disimpan Ke Luar Negeri Dalam Penegakan Hukum Indonesia. Jurnal Belo, Volume 5 Nomor 1. DOI: https://doi.org/10.30598/belovol5issue1page10-31

DOI: https://doi.org/10.30598/belovol6issue1page73-88 
[4] Lokollo, L., Salamor, Y. B., \& Ubwarin, E. (2020). Kebijakan Formulasi Undang-undang Narkotika Dalam Legalisasi Penggunaan Ganja Sebagai BahanPengobatan di Indonesia. Jurnal Belo, Volume 5 Nomor 2. DOI: https://doi.org/10.30598/belovol5issue2page1-20

[5] Mawati, E., Takariawan, A., \& Sulistiani, L. (2020). Kebijakan Hukum Pidana Mengenai Rehabilitasi Psikososial Korban Tindak Pidana Terorisme Dalam Sistem Peradilan Pidana. Jurnal Belo, Volume 5, Nomor 2, 34-56. DOI : https://doi.org/10.30598/belovol5issue2page34-56

[6] Patty, J. (2019). jmp Pelarangan Mantan Terpidana Korupsi Menjadi Calon Kepala Daerah Agar Menimbulkan Efek Jera. Jurnal Belo, 5(1), 1-9. https://doi.org/10.30598/belovol5issuelpage1-9

[7] Susilo, A. (2020). Coronavirus Disease 2019: Tinjauan Literatur Terkini. Jurnal Penyakit Dalam Indonesia, Universitas Indonesia, Volume 7 Nomor 1, Hal 45. DOI : https://doi.org/10.7454/jpdi.v7i1.415

[8] Toule, Elsa R. M., (2013), Eksistensi Ancaman Pidana Mati Dalam UndangUndang Tindak Pidana Korupsi, Jurnal Hukum Prioris. 3 (3), 104

[9] Ubwarin, E., \& Corputty, P. (2020). Pertangungjawaban Pidana Dalam Keadaan Darurat Bencana Covid-19. Mizan: Jurnal Ilmu Hukum, Volume 9 Nomor 1. Hal 6. DOI : $\underline{\text { https://doi.org/10.32503/mizan.v9i1.1043 }}$

[10] Ubwarin, E., \& Salamor, Y. B. (2017). Mekanisme Pengembalian Kerugian Negara oleh Terpidana yang Meninggal Dunia Pasca Putusan Mahkamah Konstitusi Nomor 25/PUU-XIV/2016. Jurnal Muara Ilmu Sosial, Humaniora, dan Seni ,Volume 2 Nomor $1.41-57$ DOI : https://doi.org/10.24912/jmishumsen.v1i1.334

[11] Fadillah A. N., 'M. I. A. A. (2020). Optimalisasi Penegakan Hukum Pidana Terhadap Tindak Pidana Perikanan (Studi Perbandingan Hukum Pidana Di 
Bidang Perikanan). Sasi, Volume 26 Nomor 2. DOI : https://doi.org/10.47268/sasi.v26i2.280

\section{Buku}

[12] Andi Hamzah, (2015) Pemberantasan Korupsi Melalui Hukum Nasional dan Internasional, Jakarta : Raja Grafindo Persada.

[13] Romli Atmasasmita, (2016) Sistem Peradilan Pidana (Criminal Justice System), Perspektif Eksistensialisme dan Abolisionisme, Bandung: Binacipta.

[14] Muladi dan Barda Nawawi Arief, (2015) Teori-Teori dan Kebijakan Pidana, Alumni, Bandung.

[15] Mahrus Ali, (2017), Dasar-dasar Hukum Pidana, Jakarta: Sinar Grafika.

[16] Kanter E. Y. dan Sianturi S. R, (2017) Asas-Asas Hukum Pidana Di Indonesia Dan Penerapannya, Jakarta: Storia Grafika.

[17] Andi Hamzah, (2016) Asas-asas Hukum Pidana, Rineka Cipta, Jakarta.

[18] Jan Remmelink, (2013) Hukum Pidana Komentar atas Pasal-Pasal Terpenting dari Kitab Undang Undang Hukum Pidana Belanda dan Padanannya Ddalam Kitab undang Undang Hukum Pidana Indonesia, Gramedia Pusaka Utama, Jakarta.

\section{Lain-lain}

[19] https://www.sehatq.com/Pengertian-Penyakit-Endemik-dan-Jenis-yang-MasihAda-di-Indonesia, diakases 19 Juli 2020

[20] S. Mailoa, Perilaku dan Budaya Korupsi Dalam Konteks Penegakan Hukum di Indonesia, Pidato Pengukuhan Guru Besar Dalam Bidang Ilmu Hukum Pidana pada Fakultas Hukum Universitas Pattimura, 29 April 2006.

DOI: https://doi.org/10.30598/belovol6issue1page73-88 Copyright (c) 2020 Author 